\title{
PENGEMBANGAN MEDIA PEMBELAJARAN GAME TAX ADMINISTRATION MILLIONAIRE QUIZ UNTUK MATA PELAJARAN ADMINISTRASI PAJAK
}

\section{DEVELOPMENT OF EDUCATIONAL GAME AS LEARNING MEDIA FOR STUDY TAX ADMINISTRATION}

\author{
Oleh: \\ Zulfri Adhi Wibowo \\ Pendidikan Akuntansi Universitas Negeri Yogyakarta \\ Zulfri.adhi@gmail.com
}

\section{Mahendra Adhi Nugroho}

Staf Pengajar Jurusan Pendidikan Akuntansi Universitas Negeri Yogyakarta

\begin{abstract}
Abstrak
Penelitian ini bertujuan untuk: 1) Mengembangkan game edukatif sebagai media pembelajaran Administrasi Pajak bagi siswa kelas XI Akuntansi SMK YPE Sawunggalih Kutoarjo, 2) Mengetahui kelayakan game edukatif Tax Administration Millionaire Quiz berdasarkan penilaian ahli materi, ahli media, dan siswa. Penelitian ini merupakan penelitian pengembangan atau Research and Development ( $\mathrm{R} \& \mathrm{D})$ yang diadaptasi dan dimodifikasi dari model pengembangan Borg \& Gall (1983). Teknik pengumpulan data menggunakan angket. Teknik analisis data secara deskriptif kualitatif dan kuantitatif. Hasil penelitian menunjukkan pengembangan game edukatif Tax Administration Millionaire Quiz menggunakan aplikasi Adobe Flash dan melalui 5 tahap pengembangan yaitu: 1) Studi pendahuluan, 2) Perencanaan, 3) Pengembangan produk awal, 4) Uji coba dan evaluasi, 5) Produk akhir dan penyebaran. Kelayakan game edukatif ini diperoleh melalaui lima tahapan penilaian yang dilakukan pada tahap pengembangan produk awal serta uji coba dan evaluasi. Tingkat kelayakan rata-rata skor berdasarkan penilaian: 1) Ahli materi diperoleh 4,16 (Layak), 2) Ahli media diperoleh 4,42 (Sangat Layak), 3) Uji coba perorangan diperoleh 4,55 (Sangat Layak), 4) Uji coba kelompok kecil diperoleh 4,30 (Sangat Layak), 5) Uji coba lapangan diperoleh 4,37 (Sangat Layak). Dari hasil penilaian kelayakan tersebut dapat disimpulkan bahwa game edukatif Tax Administration Millionaire Quiz "Layak" digunakan sebagai media pembelajaran Administrasi Pajak.
\end{abstract}

Kata Kunci : Game edukatif, media pembelajaran, Tax Administration Millionaire Quiz, SMK, Administrasi Pajak, Borg \& Gall.

\section{Abstract}

This research aims to: 1) Develop an educational game as Tax Administration learning media for student class XI at SMK YPE Sawunggalih Kutoarjo, 2) Determine the feasibility of educational game of Tax Administration Millionaire Quiz based assessment from subject matter expert, media expert, and students. This research adapted and modified from Borg and Gall (1983) development model which is a type of Research and Development ( $R$ \& $D)$. Data collection technique in this research using a questionnaire. Data analyzed technique was done by descriptive of qualitative and quantitative. The research results showed that 
development of educational game of Tax Administration Millionaire Quiz using Adobe Flash Aplication and passed 5 stage: 1) A pleminiary study, 2) Planning, 3) Develop pleminiary form of product, 4) Testing and evaluation, 5) Final product and dissemination. The feasibility level of this educational game obtained from five phase of assessment that conducted on stage of develop pleminiary form of product, also on stage of testing and eveluation. Mean score's feasibility according to assessment of: 1) Subject matter expert had 4,16 (Feasible), 2) Media expert had 4,42 (Very Feasible), 3) individual testing had 4,55 (Very Feasible), 4) Small group testing had 4,30 (Feasible), 5) Field testing had 4,37 (Very Feasible). The educational game of Tax Administration Millionaire Quiz is feasible for use as Tax Administration learning media.

Keywords: Educational Game, Learning Medium, Tax Administration Millionaire Quiz, SMK (Vocational High School), Tax Administration, Borg \& Gall.

\section{PENDAHULUAN}

Pada masa sekarang, perkembangan ilmu pengetahuan dan teknologi berjalan begitu pesat. Keadaan ini menuntut kehidupan di zaman ini tidak dapat terlepas dari teknologi terkini. Teknologi-teknologi yang dikembangkan pasti memiliki manfaat bagi kehidupan manusia, yaitu untuk mempermudah dan membantu kegiatan sehari-hari manusia di berbagai bidang.

Dunia pendidikan sebagai salah satu bidang kegiatan manusia memperoleh dampak positif dengan adanya perkembangan teknologi. Perkembangan teknologi ini mendorong dunia pendidikan untuk selalu berupaya melakukan pembaharuan dan memanfaatkan teknologi yang ada dalam proses pembelajaran. Salah satu sekolah yang telah memanfaatkan teknologi dalam pembelajaran adalah SMK YPE Sawunggalih Kutoarjo. Pemanfaatan teknologi ini berupa fasilitas laboratorium komputer pada masing-masing jurusan, serta pengadaan $L C D$ projector pada setiap ruang kelas.

Pemanfaatan teknologi ini selain diwujudkan sekolah juga harus dilakukan oleh guru. Guru dituntut untuk mampu menggunakan fasilitas teknologi yang telah disediakan. Di samping itu, guru juga dituntut untuk mampu mengembangkan media pembelajaran yang memanfaatkan teknologi tersebut.
Berdasarkan hasil observasi di SMK YPE Sawunggalih Kutoarjo di kelas XI Akuntansi, guru belum memanfaatkan fasilitas berbasis teknologi secara optimal. Dalam pembelajaran guru masih jarang menggunakan LCD projector. Guru lebih sering menjelaskan materi secara konvensional. Permasalah lain muncul karena siswa tidak memiliki buku teks, yang disebabkan buku kurikulum 2013 untuk mata pelajaran produktif belum diterbitkan pemerintah. Dampaknya proses pembelajaran menjadi tidak efisien karena siswa harus menulis materi terlebih dahulu baru setelah itu guru menjelaskan materi tersebut.

Selain permasalahan di atas, ditemukan masalah belum dikembangkannya media pembelajaran berbasis teknologi oleh guru Administrasi Pajak. Pada pembelajaran Administrasi Pajak biasanya guru akan mendiktekan materi terlebih dahulu dan siswa menulis, lalu guru akan menjelaskan materi, dan setelah materi selesai guru akan memberikan soal latihan. Cakupan yang cukup banyak juga membuat siswa sulit untuk memahami materi Administrasi Pajak. Proses pembelajaran yang monoton membuat siswa cepat jenuh dan bosan dalam mengikuti pembelajaran. Hal ini menjadi tantangan bagi guru untuk menciptakan pembelajaran yang menyenangkan dan menarik bagi siswa. 
Salah satu cara menciptakan pembelajaran yang menyenangkan yaitu dengan penggunaan media pembelajaran interaktif. Menurut Rossi dan Briedle (1996) dalam Wina Sanjaya (2013: 163) media pembelajaran adalah semua alat yang dapat digunakan untuk mencapai tujuan pendidikan, sedangkan interaktif memiliki arti saling aktif (http:kbbi.web.id/interaktif). Oleh karena itu, media pembelajaran interaktif merupakan semua alat atau bahan untuk mencapai tujuan pembelajaran yang dapat mengajak siswa terlibat aktif dalam pembelajaran

Media pembelajaran interaktif berbasis teknologi ada berbagai macam bentuk dan cara pengembangannya. Merujuk fasilitas yang dimiliki sekolah, media yang dapat dikembangkan yaitu dengan memanfaatkan komputer atau sering disebut Computer Assisted Instruction (CAI). CAI merupakan penggunaan komputer dalam penyampaian bahan ajar yang melibatkan siswa secara aktif serta memperbolehkan adanya umpan balik. CAI dapat berbentuk tutorial, praktik, latihan, simulasi, ataupun game.

Game sebagai media pembelajaran interaktif memiliki potensi yang cukup bagus. Pada saat ini pemafaatan game sebagai media pembelajaran masih belum banyak. Padahal game apabila dikembangkan secara tepat dapat menjadi alternatif media pembelajaran yang menarik. Hal ini karena game itu menyenangkan dan menghibur (Henry, 2010: 54), sehingga game diminati banyak orang. Hal ini dapat dijadikan landasan bagi guru untuk mencoba mengemas pembelajaran dengan game.

Game sebagai media pembelajaran interaktif berbasis komputer ini akan diintegrasikan dengan materi ajar. Dari adanya pengembangan media pembelajaran berbentuk game ini, diharapkan proses pembelajaran menjadi menyenangkan sehingga siswa dapat lebih termotivasi untuk belajar.
Salah satu jenis game yang ada adalah quiz game. Quiz game merupakan game yang pemainnya akan berperan sebagai peserta sebuah kuis. Quiz game dapat berupa adaptasi dari kuis yang ada di dunia nyata, seperti kuis Who Wants to be a Millionaire. Berdasarkan hasil observasi menggunakan angket terhadap 48 siswa SMK YPE Sawunggalih Kutoarjo tentang pengetahuan dan ketertarikan siswa terhadap kuis Who Wants to be a Millionaire. Diperoleh hasil 43 siswa menyatakan mengetahui, 45 siswa menyatakan kuis Who Wants to be a Millionaire menarik, dan 44 siswa menyatakan tertarik untuk bermain sebagai peserta kuis Who Wants to be a Millionaire. Dari data tersebut dapat dilihat sebagian besar siswa memiliki ketertarikan terhadap kuis Who Wants to be a Millionaire, sehingga kuis ini dapat diadaptasi dan dijadikan alternatif dalam mengembangkan game yang akan digunakan sebagai media pembelajaran.

Dalam mengembangkan game berbasis komputer ada beberapa software yang dapat digunakan salah satunya Adobe Flash. Adobe Flash ini merupakan program yang bersifat open platform yang artinya digunakan di perangkat komputer manapun. Bagi orang awam Adobe Flash dianggap lebih bersahabat karena dalam pembuatan aplikasi, apa yang dibuat langsung bisa terlihat pada stage. Meskipun begitu karena kebanyakan guru tidak memiliki basic IT di bidang pemrograman, sehingga saat ini pengembangan media pembelajaran yang berbasis Adobe Flash belum banyak ditemukan terutama dalam pembelajaran Administrasi Pajak.

Berdasarkan uraian di atas, maka penulis tertarik untuk mengembangkan media pembelajaran berbentuk game edukatif Tax Millionaire Administration Quiz untuk mata pelajaran Administrasi Pajak bagi siswa kelas XI Akuntansi SMK YPE Sawunggalih Kutoarjo. 


\section{METODE PENELITIAN}

\section{Jenis Penelitian}

Penelitian ini akan menggunakan jenis penelitian Research and Development (R\&D). "Educational Reaserch and Development $(R \& D)$ is a process used to develop and validate educational products" (Borg \& Gall, 1983: 772). Dari pengertian tersebut Borg \& Gall menjelaskan penelitian $\mathrm{R} \& \mathrm{D}$ merupakan proses yang dipakai untuk mengembangkan dan memvalidasi produk pendidikan. Produk yang akan dikembangkan dalam penelitian ini adalah game edukatif Tax Administration Millionaire Quiz dengan materi Administrasi Pajak.

\section{Tempat dan Waktu Penelitian}

Penelitian ini akan dilakukan di SMK YPE Sawunggalih Kutoarjo yang beralamat di Jalan Semawungdaleman Kecamatan Kutarjo Kabupaten Purworejo. Penelitian ini akan dilaksanakan pada bulan Desember 2014 - Mei 2015 dan untuk tahap pelaporan pada bulan Mei Juni 2015.

\section{Subjek Penelitian}

Subjek dari penelitian ini adalah sebagai berikut:

a. Validator yang terdiri dari dua orang ahli materi (dosen Jurusan Pendidikan Akuntansi UNY dan guru SMK YPE Sawunggalih Kutoarjo) dan satu orang ahli media pembelajaran (dosen Jurusan Pendidikan Akuntansi UNY).

b. Lima siswa pada uji coba perorangan, 15 siswa pada uji coba kelompok keil, dan 48 siswa pada uji coba lapangan.

\section{Prosedur}

Dalam penelitian ini digunakan model penelitian dan pengembangan Borg \& Gall yang memiliki 10 tahap pengembangan yaitu: 1) research and information collecting, 2) planning, 3) develop pleminiary form of product, 4) pleminiary field testing, 5) main product revision, 6) main field testing, 7) operational product revision, 8) operational field testing, 9) final product revision, 10) dissemination and implementation (Borg \& Gall, 1983:775).

Prosedur pengembangan menurut Borg \& Gall tersebut dalam penerapannya disesuaikan dengan kebutuhan dari produk dan materi yang dikembangkan. Dalam penelitian ini penulis memodifikasi model tersebut menjadi 5 tahap utama yaitu studi pendahuluan, perencanaa, pengembangan produk awal, uji coba dan evaluasi, serta produk akhir dan penyebaran. Masingmasing langkah ini dideskripsikan sebagai berikut:

a. Studi Pendahuluan

Pada tahap ini dilakukan analisis kurikulum dan analisis kebutuhan. Analisis kebutuhan dilakukan dengan observasi kelas XI Akuntansi di SMK YPE Sawunggalih Kutoarjo. Tahap ini dilakukan untuk memperoleh informasi tentang kondisi sesungguhnya yang terjadi di lapangan sehingga diperoleh informasi tentang penggunaan dan kebutuhan media pembelajaran dalam pembelajaran di kelas. Kemudian informasi yang didapatkan dianalisis dan hasilnya digunakan sebagai acuan untuk merencanakan pengembangan.

b. Perencanaan

Pada tahap perencanaan ada hal yang dilakukan yaitu:

1) Menetapkan tujuan

Pada tahap ini ditetapkan tujuan pengembangan produk. Tujuan pengembangan produk ditetapkan berdasarkan hasil dari studi pendahuluan yaitu untuk mengembangkan sebuah produk yang sesuai kebutuhan di kelas XI Akuntansi SMK YPE Sawunggalih Kutoarjo.

2) Menetapkan materi

Pada tahap ini ditentukan materi yang akan dikembangkan dalam produk. Materi ditentukan berdasarkan hasil studi pendahuluan 
yantg dilakukan yaitu materi Administrasi Pajak untuk satu tahun pelajaran.

3) Menyusun instrumen penilaian media

Instrumen yang digunakan dalam penelitian ini adalah angket atau kuisioner yang digunakan untuk menilai kelayakan dari produk yang dikembangkan. Instrumen disusun dengan skala 5 serta dilengkapi lembar komentar/saran.

c. Pengembangan Produk Awal

Hal-hal yang dilakukan pada tahap pengembangan produk awal antara lain:

1) Merancang desain awal

Pada tahap ini dilakukan beberapa kegiatan yaitu:

a) Menyusun kerangka materi serta soal

b) Menyusun flowchart

c) Membuat story board

2) Membuat produk

Pada tahap ini produk yang berupa media pembelajaran dibuat sesuai desain awal yang telah ditentukan

3) Validasi ahli materi dan ahli media

Setelah produk dibuat, selanjutnya produk media pembelajaran divalidasi oleh ahli materi dan ahli media. Hasil dari validasi ini adalah berupa penilian, koreksi, saran dan komentar yang dijadikan dasar untuk melakukan perbaikan dan pengembangan media sehingga dihasilkan media yang layak untuk diujicobakan kepada siswa.

\section{d. Uji Coba dan Evaluasi}

Uji coba dilakukan dalam tiga tahap uji coba yaitu:

1) Uji coba perorangan

Uji coba perorangan dilakukan pada 5 orang siswa kelas XI Akuntansi SMK YPE Sawungalih untuk mengetaui sejauh mana kelayakan produk pada skala terbatas. Dari hasil uji coba tersebut dilakukan analisis dan evaluasi untuk merevisi produk.

2) Uji coba kelompok kecil

Uji coba kelompok kecil dilakukan pada 15 orang siswa kelas XI Akuntansi SMK YPE Sawungalih untuk mengetaui sejauh mana kelayakan produk pada skala menengah. Dari hasil uji coba tersebut dilakukan analisis dan evaluasi untuk merevisi produk.

3) Uji coba lapangan

Uji coba lapangan dilakukan pada 48 orang siswa kelas XI Akuntansi SMK YPE Sawungalih untuk mengetaui sejauh mana kelayakan produk pada skala luas. Dari hasil uji coba tersebut dilakukan analisis dan evaluasi untuk merevisi produk.

e. Produk Akhir dan Penyebaran

Produk akhir yang dihasilkan yang berupa media pembelajaran game edukatif Tax Administration Millionaire Quiz yang sudah direvisi berdasarkan uji coba lapangan. Produk akhir ini kemudian diberikan atau disebarkan kepada sekolah yang bersangkutan.

\section{Data, Teknik Pengumpulan Data, dan Instrumen}

a. Jenis Data

Data yang dikumpulkan dalam penelitian ini berupa data kualitatif dan kuantitatif.

b. Teknik Pengumpulan Data

Teknik yang digunakan untuk pengumpulan data pada penelitian ini yaitu angket. "Angket adalah teknik pengumpulan data yang dilakukan dengan cara memberi seperangkat pertanyaan atau pernyataan tertulis kepada responden untuk dijawabnya" (Sugiyono, 2012: 199).

c. Instrumen Pengumpulan Data

Untuk memperoleh data tentang pengembangan game edukatif Tax Administration Millionaire Quiz ini 
digunakan instrumen angket. Angket diberikan kepada ahli media, ahli materi, guru (praktisi pendidikan), dan siswa. Angket berupa lembar cheklist dengan skala Likert (skala 5) dengan alternatif jawaban sangat setuju, setuju, netral, tidak setuju, dan sangat tidak setuju.

\section{Teknik Analisis Data}

a. Data kualitatif

Data kualitatif pada penelitian ini berupa saran/ masukan yang diberikan oleh dosen ahli media, dosen ahli materi, guru, dan siswa. Data kualitatif ini dianalisis secara deskriptif.

b. Data kuantitatif

Data kuantitatif pada penelitian ini diperoleh dari angket penilaian yang diberikan kepada dosen ahli materi, ahli media, guru dan siswa. Pada data angket karena data yang diperoleh dari angket tersebut masih kualitatif, maka data tersebut kemudian dianalisis dengan langkahlangkah berikut:

1) Mengkonversi data kualitatif menjadi kuantitatif dengan ketentuan skoring berikut ini:

Tabel 1. Ketentuan pemberian skor

\begin{tabular}{|l|c|}
\hline \multicolumn{1}{|c|}{ Kriteria } & Skor \\
\hline SS (Sangat Setuju) & 5 \\
\hline S (Setuju) & 4 \\
\hline N (Netral) & 3 \\
\hline TS (Tidak Setuju) & 2 \\
\hline STS (Sangat Tidak Setuju) & 1 \\
\hline
\end{tabular}

(Eko Putro Widyoko, 2009: 236) dengan modifikasi

2) Menghitung rata-rata skor dari setiap aspek menggunakan rumus sebagai berikut :

$$
\bar{\chi}=\frac{\sum \chi}{N}
$$

Keterangan:

$$
\begin{array}{ll}
\bar{\chi} & =\text { Skor rata-rata } \\
\sum \chi & =\text { Jumlah skor }
\end{array}
$$

$$
N \quad=\text { jumlah subjek }
$$

(Sukardjo, 2005: 52)

3) Rata-rata skor yang diperoleh diinterpretasikan secara kualitatif dengan menggunakan rumus konversi skor skala 5 berikut:

Tabel 2. Pedoman Konversi Skor

\begin{tabular}{|c|c|c|}
\hline Skor & $\begin{array}{c}\text { Interval } \\
\text { Skor }\end{array}$ & Kategori \\
\hline 1. & $\begin{array}{c}\text { Sangat } \\
\text { Layak }\end{array}$ & $\mathrm{X}>\bar{X}+1,80 \mathrm{Sbi}$ \\
\hline 2. & Layak & $\begin{array}{c}\bar{X}+0,60 \mathrm{SBi}<\mathrm{X} \leq \bar{X}+ \\
1,80 \mathrm{SBi}\end{array}$ \\
\hline 3. & Cukup & $\begin{array}{r}\bar{X}-0,60 \mathrm{SBi}<\mathrm{X} \leq \bar{X}+ \\
0,60 \mathrm{SBi}\end{array}$ \\
\hline 4. & Kurang & $\begin{array}{c}\bar{X}-1,80 \mathrm{SBi}<\mathrm{X} \leq \bar{X}- \\
0,60 \mathrm{SBi}\end{array}$ \\
\hline 5. & $\begin{array}{c}\text { Sangat } \\
\text { Kurang }\end{array}$ & $\mathrm{X} \leq \bar{X}-1,80 \mathrm{SBi}$ \\
\hline
\end{tabular}

Tabel 3. Pedoman Konversi Skor_2

\begin{tabular}{|c|c|c|}
\hline Skor & $\begin{array}{c}\text { Interval } \\
\text { Skor }\end{array}$ & Rentang \\
\hline 1. & Sangat Layak & $\mathrm{X}>4,20$ \\
\hline 2. & Layak & $3,40<\mathrm{X} \leq 4,20$ \\
\hline 3. & Cukup & $2,60<\mathrm{X} \leq 3,40$ \\
\hline 4. & Kurang & $1,80<\mathrm{X} \leq 2,60$ \\
\hline 5. & $\begin{array}{c}\text { Sangat } \\
\text { Kurang }\end{array}$ & $\mathrm{X} \leq 1,80$ \\
\hline
\end{tabular}

Keterangan:

$\mathrm{X}=$ Skor aktual (skor yang diperoleh)

$\overline{\mathrm{X}}=($ Rerata ideal $)$

$=1 / 2($ skor maksimum + skor minimum $)$

$=1 / 2(5+1)$

$=3$

$$
\begin{aligned}
\mathrm{SBi} & =(\text { Simpangan Baku Ideal }) \\
& =1 / 6 \quad \text { Skor maksimum }- \text { skor } \\
& \text { minimum }) \\
& =1 / 6(5-1) \\
& =0,67
\end{aligned}
$$

(Sukardjo, 2005: 53) 
HASIL PENELITIAN DAN PEMBAHASAN

\section{Langkah-Langkah Pengembangan Media}

a. Studi Pendahuluan

1) Analisis Kebutuhan

Berdasarkan observasi yang dilakukan diidentifikasi potensi dan peramsalahan yang ada di SMK YPE Sawunggalih Kutoarjo antara lain:

a) SMK YPE Sawunggalih telah memiliki fasilitas berbasis teknologi seperti laboratorium komputer dan $L C D$ projector, namun pemakaian fasilitas teknologi yang ada belum optimal

b) Dalam pembelajaran guru masih menggunakan metode konvensional dan tanpa inovasi sehingga siswa cepat merasa bosan dan jenuh dalam proses pembelajaran

c) Belum adanya buku teks pegangan bagi siswa, karena buku teks produktif kurikulum 2013 belum diterbitkan pemerintah

d) Diperlukan adanya invoasi dalam pembelajaran, seperti media pembelajaran yang menarik yang digunakan agar pembelajaran menjadi menyenangkan agar siswa lebih termotivasi untuk belajar

2) Analisis Kurikulum

Pada tahap analisis kurikulum, dilakukan kajian terhadap kompetensi minimal yang harus dicapai oleh siswa. Analisis ini dilakukan untuk mengetahui Kompetensi Dasar yang dapat dimuat dalam game yang akan dikembangkan. Pada mata pelajaran Administrasi Pajak, terdapat sembilan kompetensi dasar (KD).

\section{b. Perencanaan}

1) Menetapkan tujuan dan materi

Berdasarkan studi pendahuluan yang dilakukan maka dibuat dan ditetapkan tujuan pengembangan produk yaitu untuk menghasilkan media pembelajaran yang menarik berbentuk game yang diintegrasikan dengan materi pelajaran Administrasi Pajak secara lengkap dan sistematis. Pada tahap ini juga dikemukakan alasan pemilihan materi yang disajikan dalam game. Game ini akan memuat materi pelajaran Administrasi Pajak untuk satu tahun pelajaran. Hal ini dilakukan karena belum adanya buku teks pegangan siswa yang telah sesuai kurikulum 2013. Oleh karena itu diharapkan selain bermanfaat dalam proses pembelajaran di sekolah, game ini juga bisa menjadi sumber belajar mandiri siswa sebagai pengganti buku yang belum ada.

2) Menyusun Instrumen Penilaian Media

Pada tahap ini disusun instrumen penilaian media berupa angket atau kuisioner untuk ahli materi, ahli media, praktisi pembelajaran (guru), dan siswa. Angket atau kuisoner digunakan untuk menilai kelayakan media game edukatif Tax Administration Millionaire Quiz. Instrumen yang digunakan terdiri dari penilaian kelayakan dengan skala 5 dan lembar komentar/ saran.

\section{c. Pengembangan Produk Awal}

1) Merancang Desain Awal

Ada beberapa kegiatan yang dilakukan dalam merancang desain awal produk yaitu:

a) Menyusun kerangka materi dan soal

Materi dan soal disusun berdasarkan Kompetensi Dasar dan tujuan pembelajaran yang hendak dicapai. Materi yang disusun terbagi dalam 9 Kompetensi Dasar sesuai dengan silabus, sedangkan soal yang disusun berjumlah 119 soal yang terbagi dalam 7 kuis.

b) Menyusun flowchart

Setelah menyusun materi dan soal, selanjutnya penulis 
Jurnal Pendidikan Akuntansi Indonesia, Vol. XIII, No.1, Tahun 2015

Zulfri Adhi Wibowo \& Mahendra Adhi Nugroho

$85-98$

menyusun Flowchart. Flowchart merupakan bagan alir permainan yang berfungsi sebagai acuan bagi penulis dalam membuat game.

c) Menyusun storyboard

Story board merupakan deskripsi dari tiap tampilan. Story board dibuat untuk mendeskripsikan semua komponen yang ada dalam tiap tampilan. Tampilan yang ada dalam game antara lain : halaman preface, halaman menu, halaman game, halaman materi, halaman kompetensi dasar, dan halaman profil

2) Membuat Produk

Seluruh komponen yang telah disiapkan pada tahap desain selanjutnya diwujudkan menjadi game dengan bantuan aplikasi Adobe Flash. Berikut ini adalah screenshoot produk awal.

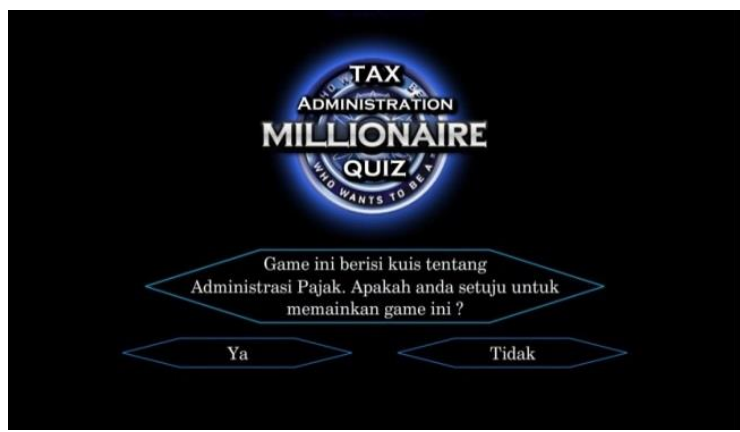

Gambar 1. Halaman Preface

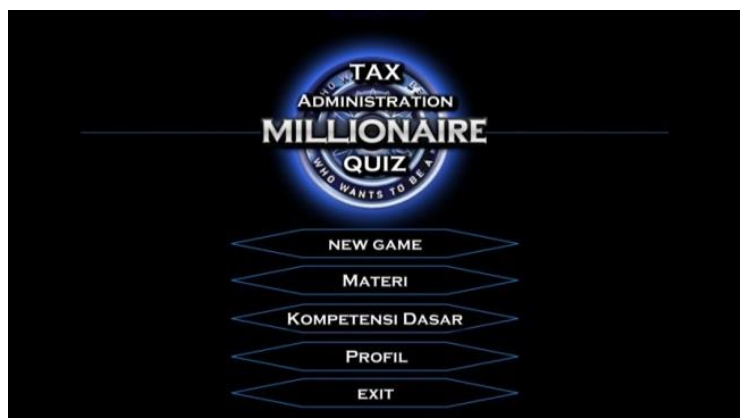

Gambar 2. Halaman Menu

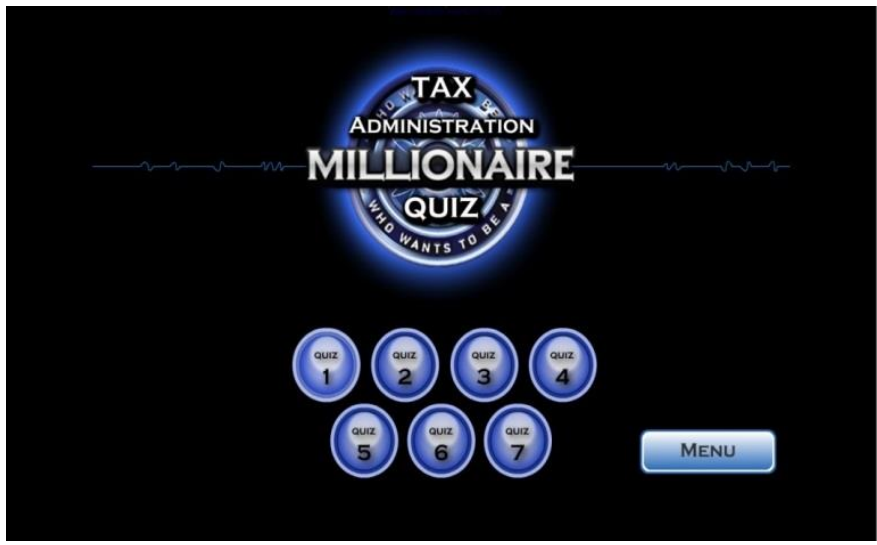

Gambar 3. Halaman New Game

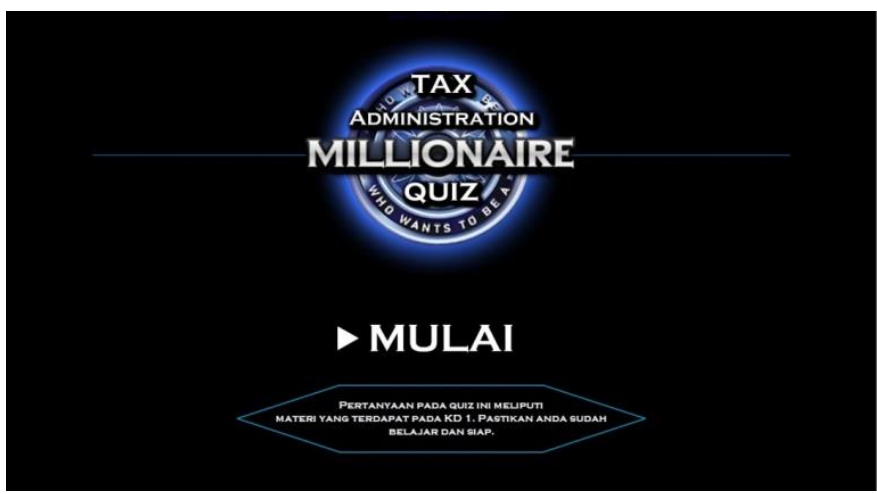

Gambar 4. Halaman Keterangan Game

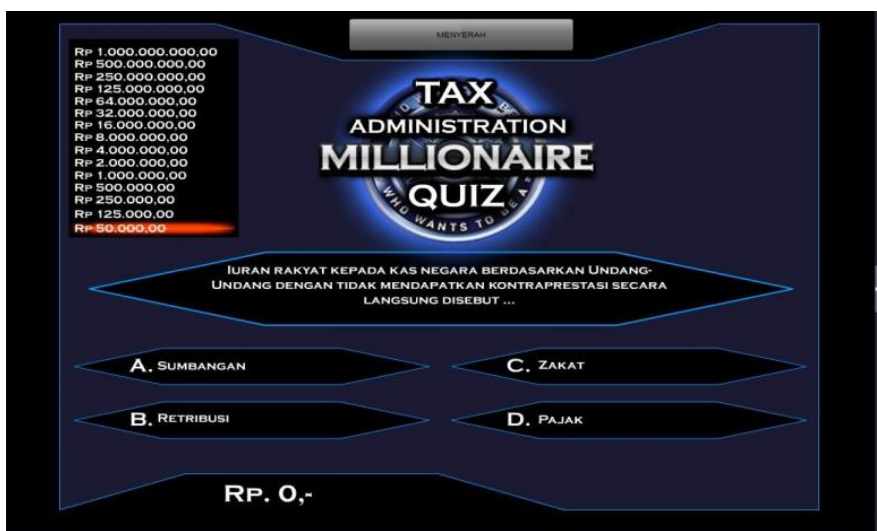

Gambar 5. Halaman Permainan

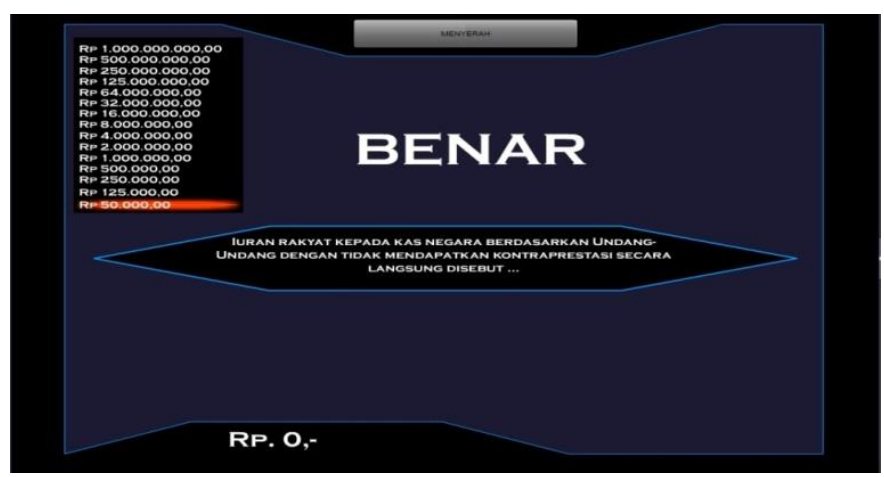

Gambar 6. Tampilan setelah menjawab 


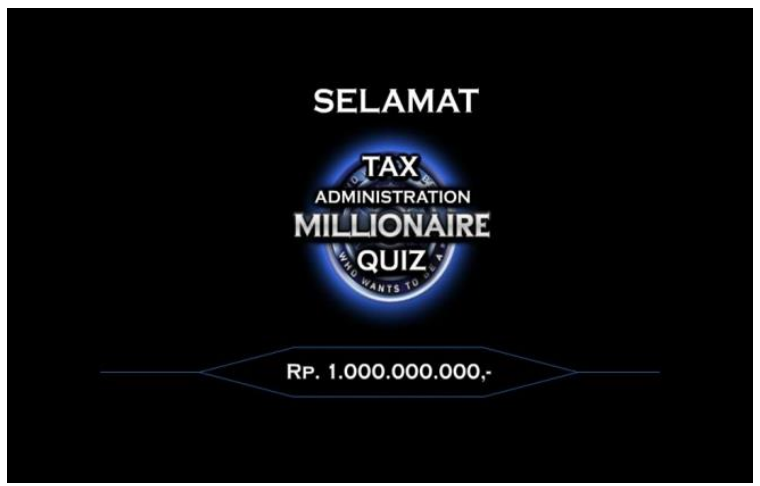

Gambar 7. Tampilan 1 Milyar

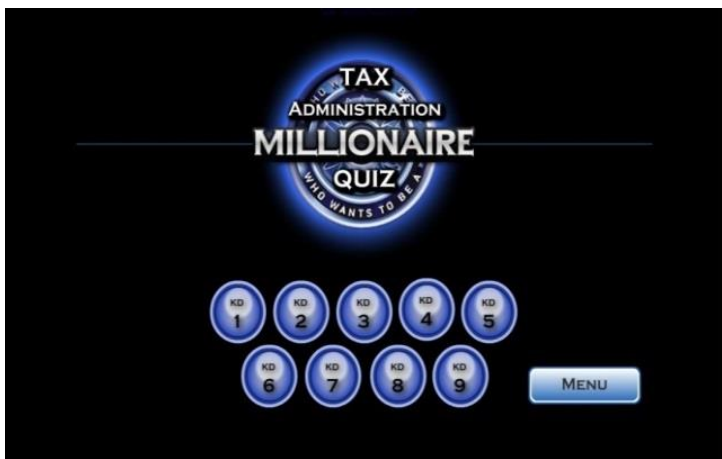

Gambar 8. Halaman Materi

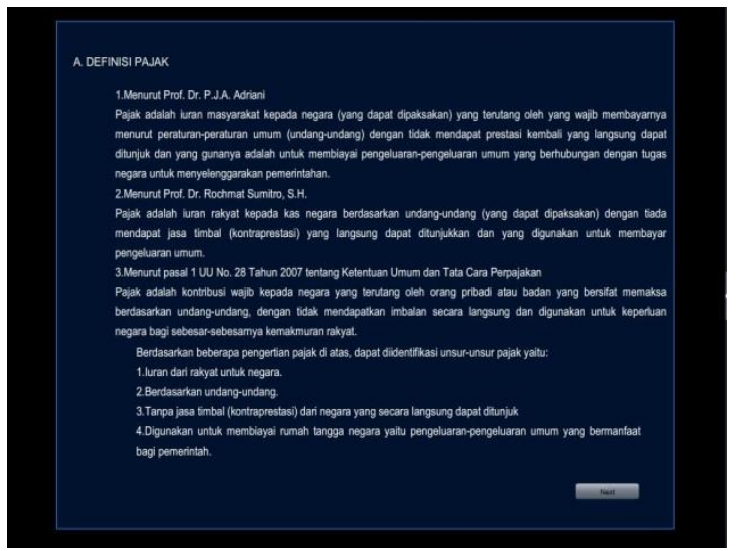

Gambar 9. Halaman dalam Materi

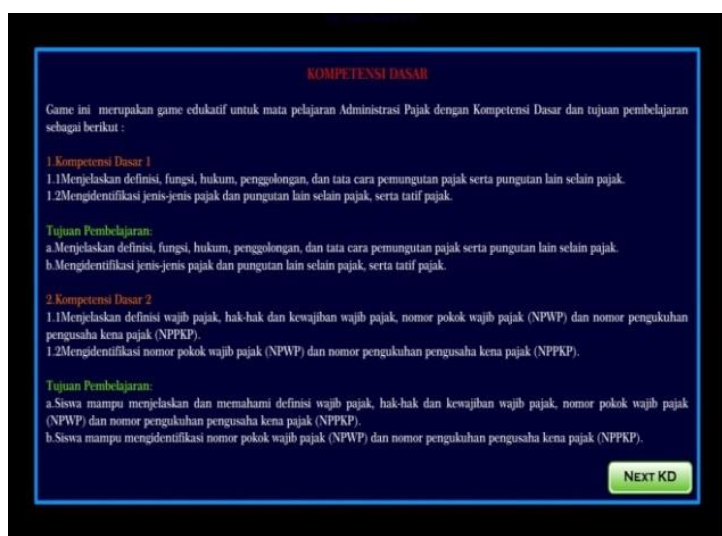

Gambar 10. Halaman KD \& KI

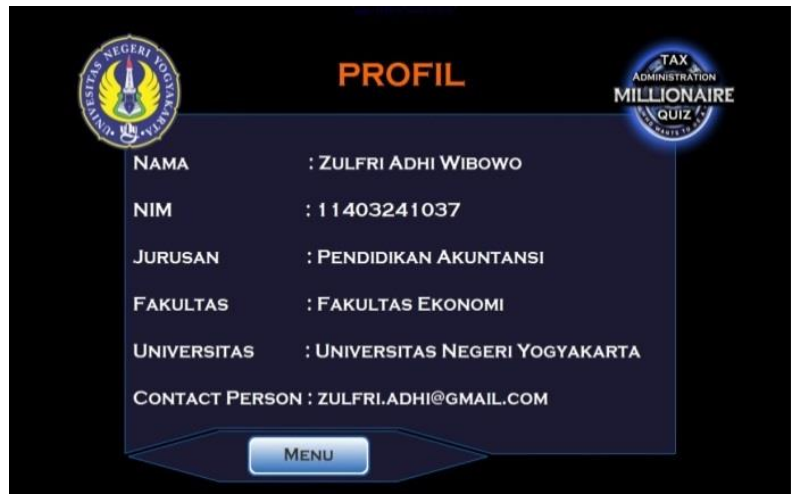

\section{Gambar 11. Halaman Profil}

3) Validasi Ahli Materi dan Ahli Media

Penilayan kelayakan media pembelajaran game edukatif Tax Administration Millionaire Quiz oleh dua orang ahli materi dan satu ahli media. Diketahui penilaian kelayakan media oleh ahli materi pada tabel 4 dan penilaian ahli media pada tabel 5 .

Tabel 4. Hasil Validasi Ahli Materi

\begin{tabular}{|c|c|c|c|c|c|}
\hline \multirow[b]{2}{*}{$\begin{array}{c}\text { Aspek } \\
\text { Kelaya } \\
\text { kan }\end{array}$} & \multicolumn{2}{|c|}{ Dosen } & \multicolumn{2}{|c|}{ Guru SMK } & \multirow[b]{2}{*}{$\begin{array}{c}\text { Rata- } \\
\text { rata }\end{array}$} \\
\hline & $\begin{array}{c}\text { Jml } \\
\text { Sko } \\
\mathbf{r}\end{array}$ & $\begin{array}{c}\text { Rat } \\
\text { a- } \\
\text { rata }\end{array}$ & $\begin{array}{c}\text { Jml } \\
\text { Sko } \\
\mathbf{r}\end{array}$ & $\begin{array}{c}\text { Rat } \\
\text { a- } \\
\text { rata }\end{array}$ & \\
\hline Materi & 47 & 4,27 & 46 & 4,18 & 4,23 \\
\hline $\begin{array}{l}\text { Kebaha } \\
\text { saan }\end{array}$ & 13 & 4,33 & 13 & 4,33 & 4,33 \\
\hline Soal & 28 & 4,00 & 27 & 3,86 & 3,93 \\
\hline Total & 88 & 4,20 & 86 & 4,12 & 4,16 \\
\hline $\begin{array}{l}\text { Kategor } \\
\text { i }\end{array}$ & & $\mathrm{L}$ & & $\mathrm{L}$ & Layak \\
\hline
\end{tabular}

Tabel 5. Hasil Validasi Ahli Media

\begin{tabular}{|l|c|c|}
\hline Aspek Kelayakan & $\begin{array}{c}\text { Jumlah } \\
\text { Skor }\end{array}$ & $\begin{array}{c}\text { Rata- } \\
\text { rata }\end{array}$ \\
\hline $\begin{array}{l}\text { 1. Rekayasa } \\
\text { Perangkat Lunak }\end{array}$ & 53 & 4,42 \\
\hline $\begin{array}{l}\text { 2. Komunikasi } \\
\text { Visual }\end{array}$ & 53 & 4,42 \\
\hline Total & 106 & 4,42 \\
\hline Kategori & $\begin{array}{c}\text { Sangat } \\
\text { Layak }\end{array}$ \\
\hline
\end{tabular}

Diketahui dari tabel 4 dan tabel 5 penilaian kelayakan oleh ahli materi diperoleh rata-rata skor 4,16 dengan kategori Layak, dan pada penilaian oleh 
ahli media mendapatkan rata-rata skor 4,42 dengan kategori Sangat Layak.

4) Revisi

Melakukan revisi terhadap media pembelajaran game edukatif Tax Administration Millionaire Quiz berdasarkan penilaian, masukan, saran dai ahli materi serta ahli media

\section{d. Uji Coba dan Validasi}

1) Uji coba perorangan

Uji coba perorangan dilakukan pada 5 siswa SMK YPE Sawunggalih Kutoarjo. Hasil penilaian siswa pada uji coba perorangan dilihat pada tabel berikut.

Tabel 6. Hasil Uji Coba Perorangan

\begin{tabular}{|l|c|c|}
\hline Aspek Kelayakan & $\begin{array}{c}\text { Jumlah } \\
\text { Skor }\end{array}$ & $\begin{array}{c}\text { Rata- } \\
\text { rata } \\
\text { Skor }\end{array}$ \\
\hline $\begin{array}{l}\text { 1. Rekayasa } \\
\text { Perangkat Lunak }\end{array}$ & 143 & 4,77 \\
\hline $\begin{array}{l}\text { 2. Desain } \\
\text { Pembelajaran }\end{array}$ & 160 & 4,57 \\
\hline $\begin{array}{l}\text { 3. Komunikasi } \\
\text { Visual }\end{array}$ & 175 & 4,38 \\
\hline Total & 478 & 4,55 \\
\hline Kategori & $\begin{array}{l}\text { Sangat } \\
\text { Layak }\end{array}$ \\
\hline
\end{tabular}

Diketahui dari tabel di atas game edukatif yang dikembangkan mendapatkan rata-rata skor 4,55 dengan kategori Sangat Layak. Pada tahap ini tidak dilakukan revisi karena tidak ada kesalahan yang ditemukan dalam game berdasarkan komentar dan saran siswa.

2) Uji coba kelompok kecil

Uji coba kelompok kecil dilakukan pada 15 siswa SMK YPE Sawunggalih Kutoarjo. Hasil penilaian siswa pada uji coba perorangan dilihat pada tabel berikut.
Tabel 7. Hasil Uji Coba Kelompok Kecil

\begin{tabular}{|l|c|c|}
\hline Aspek Kelayakan & $\begin{array}{c}\text { Jumlah } \\
\text { Skor }\end{array}$ & $\begin{array}{c}\text { Rata- } \\
\text { rata } \\
\text { Skor }\end{array}$ \\
\hline $\begin{array}{l}\text { 1. Rekayasa } \\
\text { Perangkat Lunak }\end{array}$ & 395 & 4,39 \\
\hline $\begin{array}{l}\text { 2. Desain } \\
\text { Pembelajaran }\end{array}$ & 447 & 4,26 \\
\hline $\begin{array}{l}\text { 3. Komunikasi } \\
\text { Visual }\end{array}$ & 512 & 4,27 \\
\hline Total & 1.354 & 4,30 \\
\hline Kategori & $\begin{array}{l}\text { Sangat } \\
\text { Layak }\end{array}$ \\
\hline
\end{tabular}

Diketahui dari tabel di atas game edukatif yang dikembangkan mendapatkan rata-rata skor 4,30 dengan kategori Sangat Layak. Berdasarkan komentar dan saran siswa ditemukan adanya kesalahan pada game yang perlu diperbaiki. Kesalahan yang ditemukan telah diperbaiki di tahap ini, sehingga uji coba terhadap game yang dikembangkan dapat dilanjutkan pada tahap uji coba lapangan.

3) Uji coba lapangan

Uji coba kelompok kecil dilakukan pada 48 siswa SMK YPE Sawunggalih Kutoarjo. Hasil penilaian siswa pada uji coba perorangan dilihat pada tabel berikut.

Tabel 8. Hasil Uji Coba Lapangan

\begin{tabular}{|l|c|c|}
\hline Aspek Kelayakan & $\begin{array}{c}\text { Jumlah } \\
\text { Skor }\end{array}$ & $\begin{array}{c}\text { Rata- } \\
\text { rata } \\
\text { Skor }\end{array}$ \\
\hline $\begin{array}{l}\text { 1. Rekayasa } \\
\text { Perangkat Lunak }\end{array}$ & 1.283 & 4,45 \\
\hline $\begin{array}{l}\text { 2. Desain } \\
\text { Pembelajaran }\end{array}$ & 1.454 & 4,33 \\
\hline $\begin{array}{l}\text { 3. Komunikasi } \\
\text { Visual }\end{array}$ & 1.665 & 4,34 \\
\hline Total & 4.402 & 4,37 \\
\hline Kategori & & $\begin{array}{c}\text { Sangat } \\
\text { Layak }\end{array}$ \\
\hline
\end{tabular}

Diketahui dari tabel di atas game edukatif yang dikembangakan mendapatkan rata-rata skor 4,37 dengan 
Jurnal Pendidikan Akuntansi Indonesia, Vol. XIII, No.1, Tahun 2015

Zulfri Adhi Wibowo \& Mahendra Adhi Nugroho

$85-98$

kategori Sangat Layak. Pada tahap ini tidak dilakukan perbaikan, karena berdasarkan komentar dan saran siswa tidak ada kesalahan yang ditemukan dalam game.

\section{e. Produk Akhir dan Penyebaran}

Produk akhir dari penelitian pengembangan ini adalah game edukatif Tax Administration Millionaire Quiz yang telah selesai evaluasi akhir pada uji coba lapangan. Game edukatif Tax Administration Millionaire Quiz merupakan adaptasi dari kuis Who Wants to be a Millionaire yang diwujudkan menjadi game desktop. Di mana game ini berisi materi sebagai bahan belajar, dan soal latihan yang dikemas dalam bentuk kuis. Screenshot game edukatif Tax Administration Millionaire Quiz yang dikembangkan dapat dilihat pada gambar-gambar berikut ini.

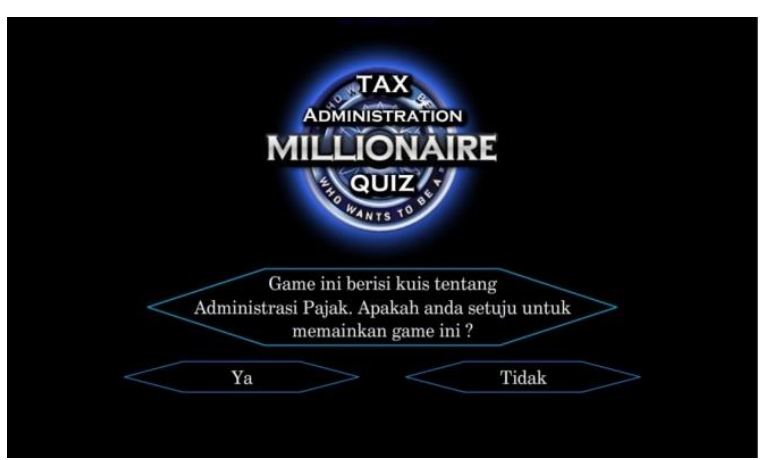

Gambar 12. Halaman Preface

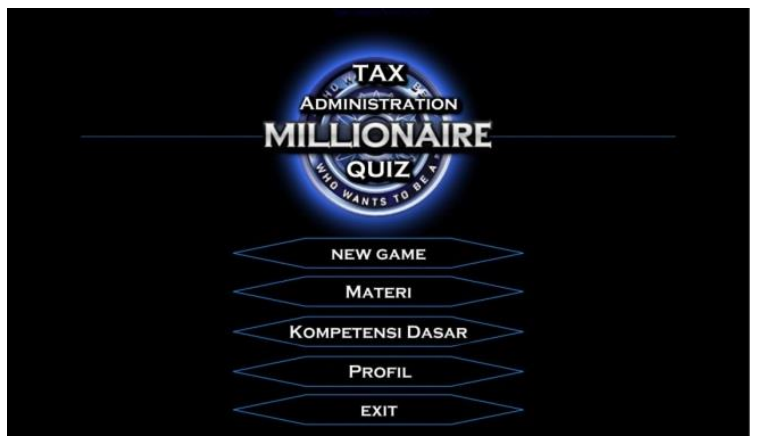

Gambar 13. Halaman Menu
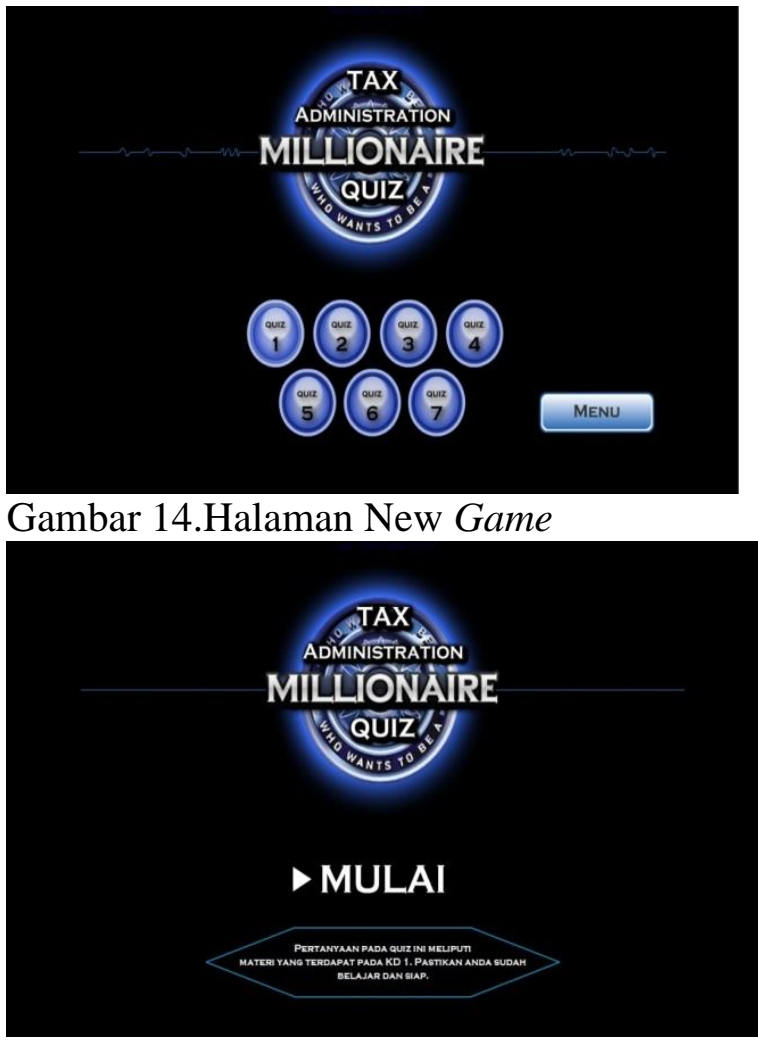

Gambar 15. Halaman Keterangan Game

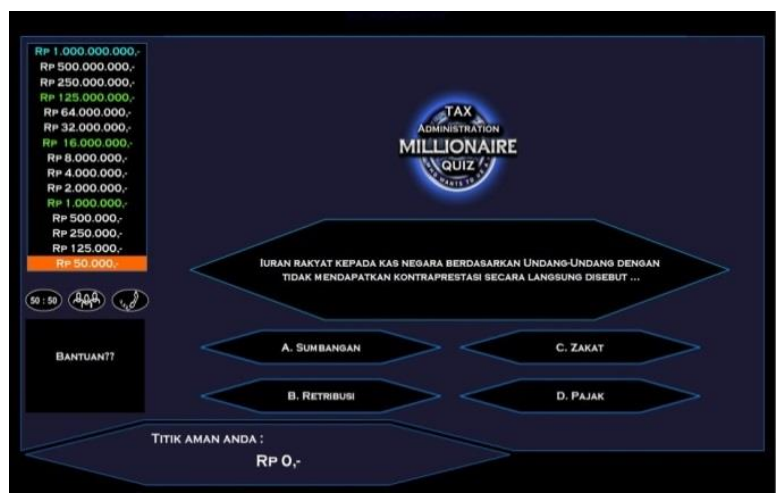

Gambar 16. Halaman Permaianan

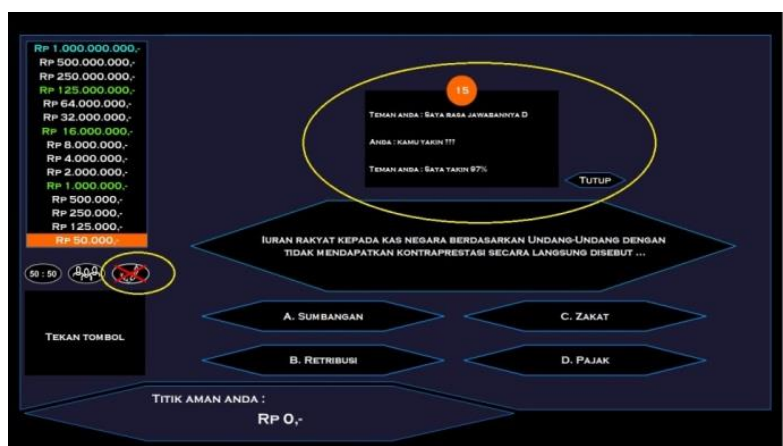

Gambar 17. Tampilan Bantuan_1 
Jurnal Pendidikan Akuntansi Indonesia, Vol. XIII, No.1, Tahun 2015

Zulfri Adhi Wibowo \& Mahendra Adhi Nugroho

$85-98$

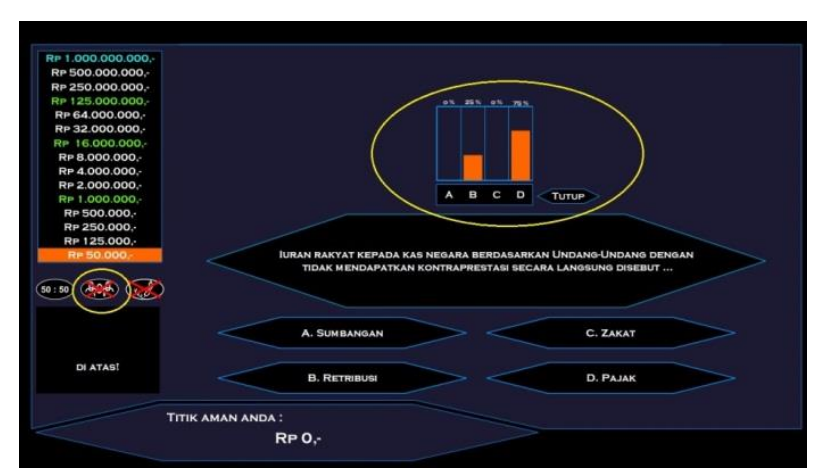

Gambar 18. Tampilan Bantuan_2

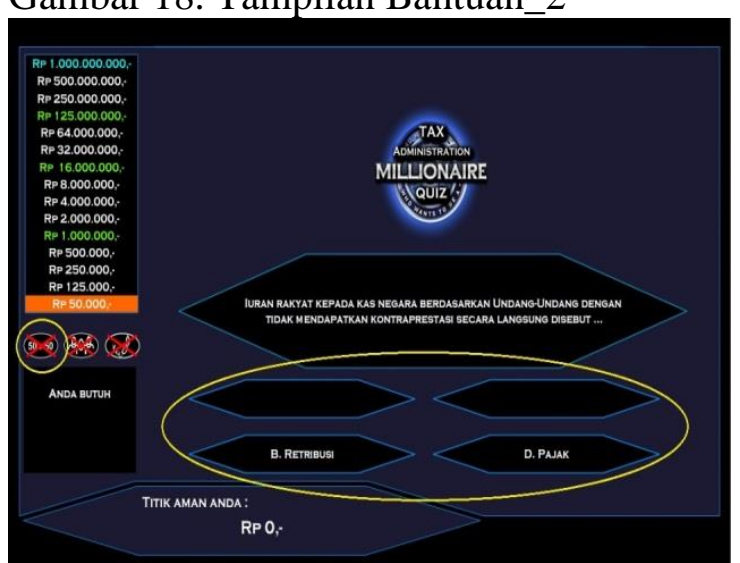

Gambar 19. Tampilan Bantuan_3

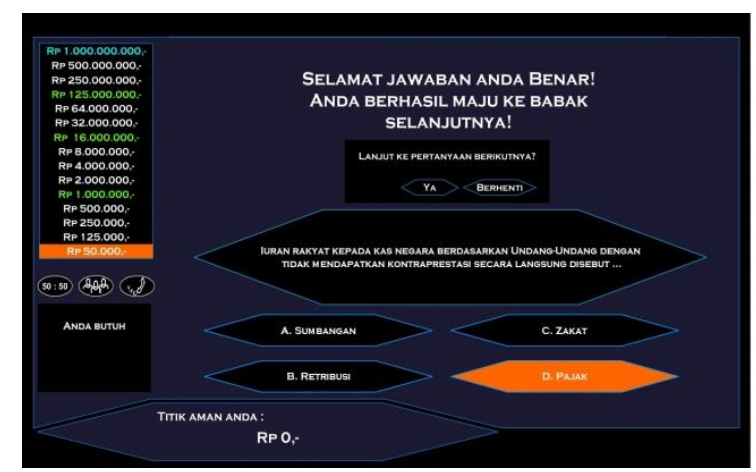

Gambar 20. Tampilan Jawaban Benar

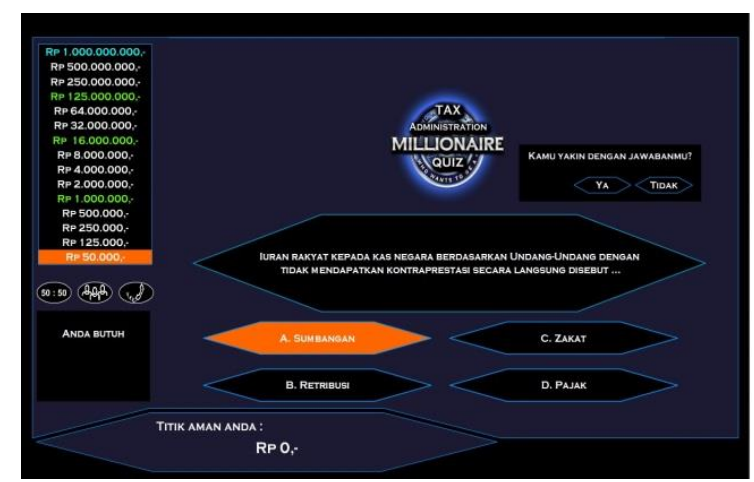

Gambar 21. Tampilan Jawaban Salah

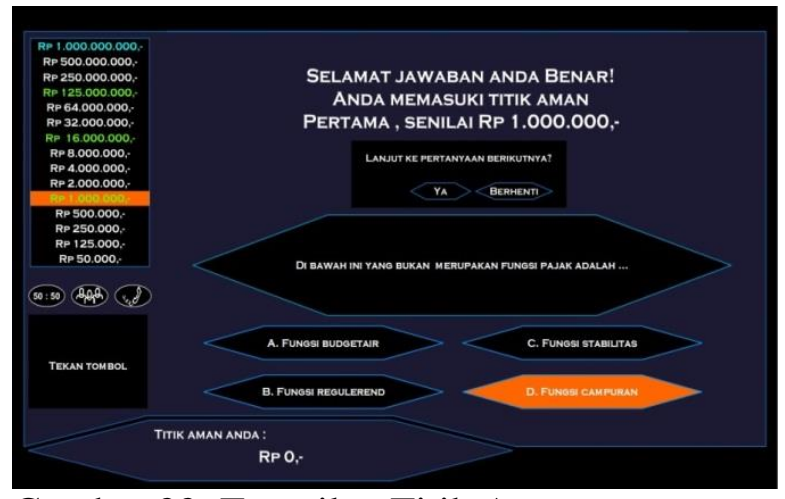

Gambar 22. Tampilan Titik Aman

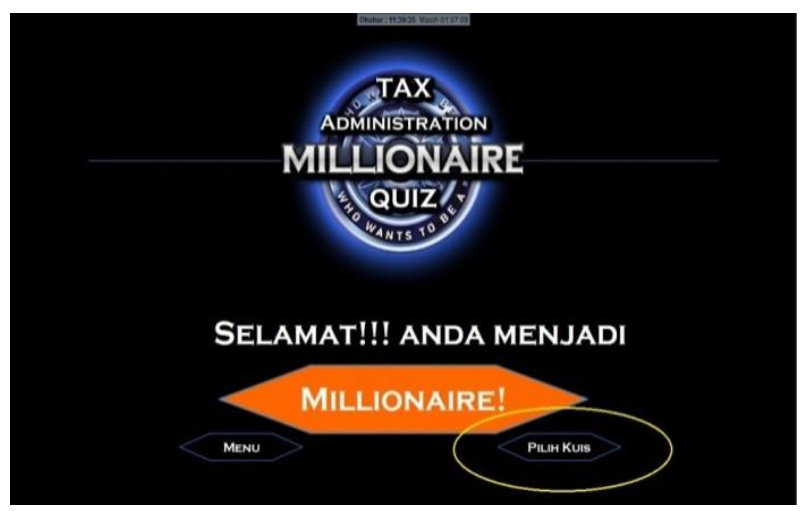

Gambar 23. Tampilan 1 Milyar

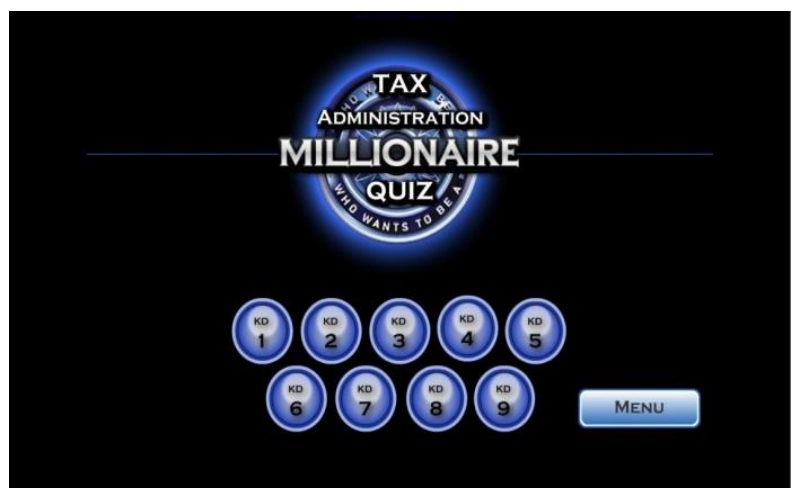

Gambar 24. Halaman Materi

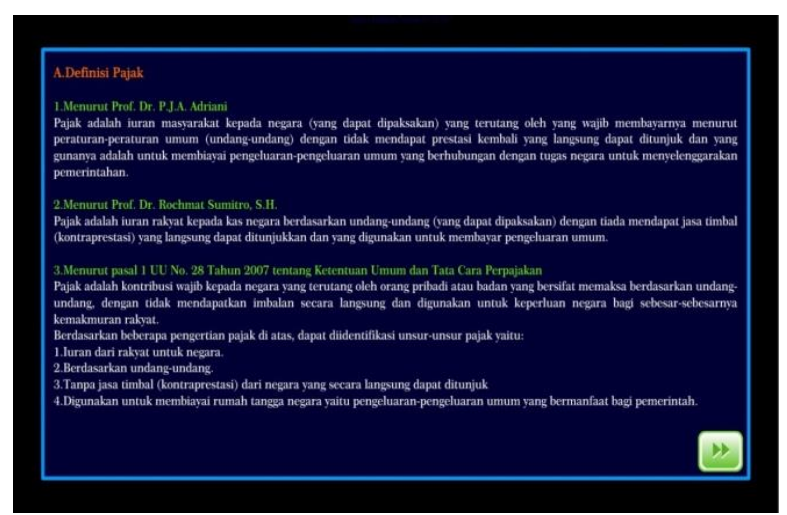

Gambar 25. Halaman Dalam Materi 


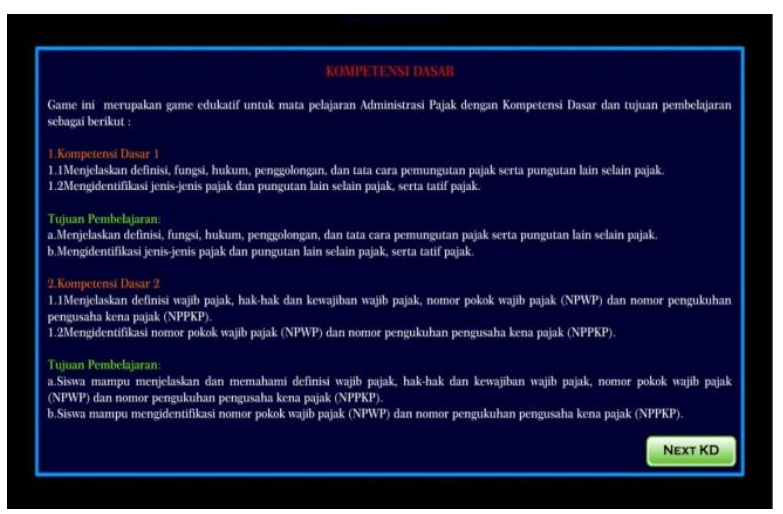

Gambar 26. Halaman KD \& KI

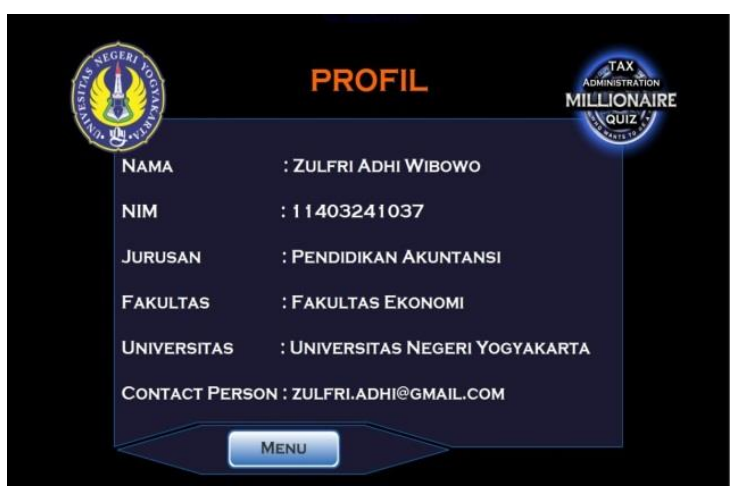

Gambar 27. Halaman Profil

Produk akhir yang telah selesai dikembangkan ini kemudian diberikan kepada sekolah. Kegiatan penyebaran produk ini bertujuan agar game yang dikembangkan tersebut bermanfaat bagi sekolah.

\section{KESIMPULAN DAN SARAN}

\section{Kesimpulan}

Berdasarkan hasil penelitian dan pembahasan maka dapat diambil kesimpulan sebagai berikut:

a. Pengembangan game edukatif Tax Administration Millionaire Quiz melewati 5 tahap utama pengembangan yaitu tahap studi pendahuluan, tahap perencanaan, tahap pengembangan produk awal, tahap uji coba dan evaluasi, serta tahap produk akhir dan penyebaran.

b. Tingkat kelayakan game edukatif Tax Administration Millionaire Quiz ditinjau berdasarkan penilaian dari ahli materi, ahli media, dan siswa. Penilaian kelayakan oleh ahli materi diperoleh nilai rata-rata 4,16 dengan kategori Layak. Penilaian kelayakan oleh ahli media diperoleh nilai ratarata 4,42 dengan kategori Sangat Layak. Serta Penilaian oleh siswa diperoleh rata-rata nilai pada masingmasing uji coba sebagai berikut: uji coba perorangan dengan rata-rata nilai 4,55 termasuk kategori Sangat Layak, uji coba kelompok kecil dengan rata-rata nilai 4,30 termasuk kategori Sangat Layak, dan uji coba lapangan dengan rata-rata nilai 4,37 termasuk kategori Sangat Layak.

\section{Saran}

Berdasarkan penelitian, keterbatasan pengembangan, dan kelebihan Game Edukatif Tax Administration Millionaire Quiz. Peneliti memberikan saran sebagai berikut :

a. Game Edukatif Tax Administration Millionaire Quiz sebagaiknya digunakan guru dalam kegiatan belajar mengajar sehingga pembelajaran menjadi bervariatif dan menambah antusias belajar siswa.

b. Game Edukatif Tax Administration Millionaire Quiz sebaiknya digunakan siswa untuk belajar mandiri di rumah sehingga dapat menambah pemahaman terhadap materi.

c. Soal yang ada dalam game dapat dikembangkan dan ditambah lagi pada setiap levelnya, sehingga ketika siswa gagal menjawab dan kembali ke level awal maka soal yang diajukan berbeda.

d. Perlu adanya penelitian lebih lanjut seperti penelitian tindakan kelas ataupun eksperimen dengan kelas kontrol, sehingga dapat mengukur efektivitas penggunaan Game Edukatif Tax Administration Millionaire Quiz sebagai media pembelajaran Administrasi Pajak. 


\section{DAFTAR PUSTAKA}

Ahmad Faiq Abror. (2012). "Mathematics Adventure Game Berbasis Role Playing Game (RPG) Maker XP sebagai Media Pembelajaran di SMP Negeri 2 Kalibawang”. Skripsi FT UNY.

Azhar Arsyad. (2011). Media Pembelajaran. Jakarta: PT Raja Grafindo Persada.

Eko Putro Widyoko. (2009). Evaluasi Program Pembelajaran. Yogyakarta: Pustaka Pelajar.

Ghea Putri Fatma Dewi. (2012). "Pengembangan Game Pengenalan Nama Hewan Dalam Bahasa Inggris Sebagai Media Pembelajaran Siswa SD Berbasis Macromedia Flash". Skripsi. UNY.

Ira Mariyon. (2014). "Pengembangan Medhia Games Flash How Wants To Be A Siaja Kanggo Ngundhakake Kawasisan Nulis Ukara Nganggo Sandhangan Wyanjana Tumrap Siswa Kelas VIII SMPN 1 Gondang Mojokerto Tahun Ajaran 2013/2014". Jurnal Baradha Vol. 2 No. 3. Diambil dari: http://ejournal.unnesa.ac.id/, pada tanggal 19 Januari 2015.

Kusuma Hadi Purnawan. (2011). "Media Pembelajaran Matematika Menggunakan Game Matematika Millionaire Berbasis Adobe Flash". Diambil dari: http://eprints.umm.ac.id, pada tanggal 19 Januari 2015.

Samuel Henry. (2010). Cerdas Dengan Game. Jakarta: PT Gramedia Pustaka Utama.

Sugiyono. (2012). Metode Penelitian Kuantitatif Kualitatif dan $R \& D$. Bandung: Afabeta.
Sukardjo. (2005). Evaluasi Pembelajaran Semester 2. Yogyakarta: PPs UNY.

Wallter R. Borg dan Meredith D. Gall. (1983). Educational Research An Introduction $\left(4^{\text {th }}\right.$ ed). New York: Longman. Inc.

Wina Sanjaya. (2013). Strategi Pembelajaran Berorientasi Standar Proses Pendidikan. Jakarta: Kencana Prenadamedia Group. 